\title{
Macro Flash-based Multimedia for Improvement of The Learning Result of Volleyball Game
}

\author{
$1^{\text {st }}$ Hartati \\ Teacher Training and Education \\ Science Faculty \\ Universitas Sriwijaya \\ Palembang, Indonesi \\ hartati@fkip.unsri.ac.id
}

\author{
$2^{\text {nd }}$ Destriana \\ Teacher Training and Education \\ Science Faculty \\ Universitas Sriwijaya \\ Palembang, Indonesia \\ Destriana@fkip.unsri.ac.id \\ $4^{\text {th }}$ Destriani \\ Teacher Training and Education \\ Science Faculty \\ Universitas Sriwijaya \\ Palembang, Indonesia \\ Destriani@fkip.unsri.ac.id
}

\author{
$3^{\text {rd }}$ Silvi Aryanti \\ Teacher Training and Education \\ Science Faculty \\ Universitas Sriwijaya \\ Palembang, Indonesia \\ arryanti@fkip.unsri.ac.id
}

\begin{abstract}
The purpose of this study is to determine the improvement of learning skill learning outcomes on teacher training and education science faculty students UNSRI class of force 2016 after using multimedia-based macro flash. This study uses classroom action research to determine the effectiveness of multimedia-based learning macro flash. Subjects in this study are physical education and health students amounting to 40 people who follow the game volleyball. The test instrument used to determine student learning outcomes is face wall-volley test. Classroom action research is done by using 2 cycles. The result of the research on the 1 st cycle showed that there was an increase of learning outcomes of the students on the first test. There were 2 students $(5 \%)$ in the good category increased to 10 students $(25 \%), 12$ students $(30 \%)$ were in enough category to increase 25 students $(62.5 \%)$, and the lesser category that initially 26 students $(65 \%)$ decreased to 5 students $(12.5 \%)$. The result in cycle 2 is that there is a significant increase of 10 students $(25 \%)$ in the good category to 37 students $(92.5 \%)$, and 3 students $(7,5 \%)$ are in enough category. The findings this study is that multimedia macroflash is effectively used to improve the learning outcomes of pasing skills on the game of volleyball.The implications of this research are macro flash based multimedia can be used as a learning media choice that can be used to improve the learning of volleyball game.
\end{abstract}

Keywords : Multimedia Macroflash, classroom action research, volleyball game

\section{INTRODUCTION}

Physical education has an enormous relationship to science and technology. Physical education is also more emphasis on the development of concepts with a variety of teaching methods in accordance with the study materials taught. Physical education according to[1]is an educational process that utilizes physical activities planned systematically aimed at developing and enhancing individuals organically, neuromosculer, perceptual, cognitive, and emotional in national education system. Physical edeucation plays an important role in the effort to create human character and quality and global competitiveness. In physical education learning very necessary appropriate learning strategies that can involve students / students as optimal as possible both the cognitive, affective and psychomotor aspects. Achievement of learning objectives physical education largely determined by the success of teaching and learning in the classroom or in the field. The success of the teaching and learning process in the classroom / field is influenced by various factors such as teachers and learners. Teachers has a role as a facilitator, mediator and motivator in charge of providing learning experiences that enable learners hindered develop the knowledge, specific to the skills and attitudes to existing facilities.

Based on the results of limited interviews on the students of teacher training and education science faculty UNSRI class of 2016, students have difficulty in understanding the basic techniques of volleyball.[2] The game of volleyball is a game that is carried out by two teams, each consisting of six people, played ball in the air to pass through the net, each of his team could only punch the ball three times. The basic volleyball technique is upper, lower bottom, service, block and smash. At the time through Home Visits learning volleyball game to deliver such material requires appropriate media so sublime students are able to understand the material. 
Basic technique should be visualized with an actual human being so that these techniques are easy to understand. Trouble understanding the material will affect student learning outcomes. This is an advanced research on the development of interactive multimedia ball game that was done before. Results of research development in the form of multimedia packed in Flashdisk and compact disk based macroflash eligible to be used with existing products then the product must be tested effectiveness. The effectiveness test used is the classroom action research method because it can see the improvement that occurs after using macroflash based multimedia. [3]Multimedia is a multiple media "or" a combination of media, communicate information in multiple ways. [4]Macromedia flash is one of the application program used to design the animation that is used today. Macromedia flash is software used by interactive learning programmer, because macromedia is classified as the easiest to use [5]. [6]While on the student activity, the cycle I get an average score of 27 which is an increase in the second cycle to 36 and 40 in cycle III with both criteria multimedia macromedia flash in learning can improve student learning activities and results. [7 ] There are differences of students results before and after instruction using computer media in Physical Education lessons. There is increasing of learning results after the students acquire learning by using computer as a medium in the Physical Education learning.

This Multimedia contains text, image, sound, video display that will be used as a learning multimedia volleyball game. This study is limited to only one technique in the game of volleyball that is the upper position. The mass formula in this research is how the multimedia effectiveness (macroflash) on the result of learning skill pasing on the game of volleyball. [8]The effectiveness of learning is the success of learning characterized by the desire of students to learn what is taught and the value obtained by students is strongly influenced by teachers because teachers are one of the factors that affect the effectiveness of learning in addition to other factors. The purpose of this study was to know learning outcome passing skills on physical education and health students force in 2016 on teacher training and education science faculty after using multimediabased macroflash.

\section{RESEARCH METHODS}

The research method used in this research is action research. [9] States that the study of class action is a reflection of learning activities in the form of an action, which deliberately appear and occur in a class together. This action research is done in the classroom so called classroom action research. Research performed by teachers on learners in schools or colleges where teachers teach with an emphasis on improving learning and learning practices. This classroom action research is carried out using 2 cycles with 1 meeting in each cycle. Data on preliminary findings as a reference for analyzing data in cycle 1. Data analysis focus only on the skill domain. Top passing skills assessment instrument using AAHPER face wall-volley test. Subject in this research is physical education and health student class of 2016 with number of 40 students on teacher training and education science faculty UNSRI.

The steps in this research is to observe the student of pemas during learning pasing on the game of volleyball. The data obtained after the observation is used as a reference to start the cycle 1 . Cycle 1 starts with the pretest pasing of the game volleyball further given the action in the form of displaying multimedia (flash) before field practice. Multimedia is displayed in a duration of 15 minutes which contains about the understanding of the basic pasch top technique and upper pasing technique, after being given the action of the spaciousness students to practice. Postest is done after the learning ends. Cycle 1 should be continued in cycle 2 because the result obtained in cycle 1 is not maximal yet. In cycle 2 the action given is broadcast multimedia (flash) with a longer duration for 25 minutes. To see the learning result pasing above then done postest again.

\section{RESULTS AND DISCUSSION}

This research is preceded by pretest or pretest test. The results obtained in this test will be preliminary data to determine the ability of learning volleyball especially top pasing technique. The data obtained is the result of the skill ability pasing above before the action against physical education and health student on teacher training and education science faculty UNSRI. The assessment norms in this study were used [10].

Table 1. AAHPER Assessment of Face Pass Wall Volley Test

\begin{tabular}{|l|l|l|l|l|l|l|l|l|}
\hline \multirow{2}{*}{$\begin{array}{l}\text { Valu } \\
\mathrm{e}\end{array}$} & \multicolumn{4}{|l|}{ Male (Sex Age) } \\
\cline { 2 - 10 } & $\begin{array}{l}11 \\
-\end{array}$ & $\begin{array}{l}12 \\
- \\
14\end{array}$ & $\begin{array}{l}15- \\
17\end{array}$ & $\begin{array}{l}18- \\
22\end{array}$ & $\begin{array}{l}9- \\
1 \\
1\end{array}$ & $\begin{array}{l}12- \\
14\end{array}$ & $\begin{array}{l}15- \\
17\end{array}$ & $\begin{array}{l}18 \\
- \\
22\end{array}$ \\
\hline 90 & 19 & 31 & 41 & 50 & 1 & 25 & 35 & 38 \\
& & & & & 3 & & & \\
\hline 80 & 15 & 26 & 37 & 48 & 8 & 17 & 24 & 27 \\
\hline 70 & 12 & 22 & 34 & 44 & 5 & 13 & 19 & 20 \\
\hline 60 & 9 & 19 & 31 & 41 & 3 & 10 & 15 & 16 \\
\hline 50 & 7 & 17 & 28 & 38 & 2 & 8 & 12 & 12 \\
\hline 40 & 5 & 14 & 24 & 35 & 1 & 6 & 9 & 9 \\
\hline 30 & 3 & 11 & 20 & 32 & 1 & 4 & 7 & 7 \\
\hline 20 & 2 & 8 & 17 & 21 & 0 & 2 & 5 & 5 \\
\hline 10 & 0 & 5 & 12 & 20 & 0 & 0 & 3 & 3 \\
\hline
\end{tabular}

[10]

Table 2. Assessment Table

\begin{tabular}{|l|l|l|}
\hline $\begin{array}{l}\mathrm{N} \\
\mathrm{o}\end{array}$ & Score & Relative Meaning \\
\hline 1 & $86-100$ & Very good \\
\hline 2 & $71.00-85.99$ & Good \\
\hline 3 & $56.00-70.99$ & Enough \\
\hline 4 & $41.00-55.99$ & Less \\
\hline 5 & $<40,99$ & Very less \\
\hline
\end{tabular}

[11] 
With reference to the above table then in the initial data can be as follows :

Table 3. Distribution of Preliminary

Test Data on Upper Pas

\begin{tabular}{|l|l|l|l|}
\hline Value & $\begin{array}{l}\text { The number } \\
\text { of students }\end{array}$ & Category & Percentage \\
\hline $86-100$ & 0 & $\begin{array}{l}\text { Very } \\
\text { good }\end{array}$ & $0 \%$ \\
\hline $71.00-85.99$ & 2 & Good & $5 \%$ \\
\hline $56.00-70.99$ & 12 & Enough & $30 \%$ \\
\hline $41.00-55.99$ & 23 & Less & $57.5 \%$ \\
\hline$<40,99$ & 3 & Very less & $7.5 \%$ \\
\hline
\end{tabular}

Based on preliminary data, it can be explained that the students are in good category as much as 2 students (5\%), enough category 12 students (30\%), 23 students $(57,5 \%)$, there are less than 3 students $(7.5 \%)$. From the data above can be concluded the result of pretest pasing game of student volleyball of semester 2 semester is in less category. With such circumstances it is necessary to take action that can improve the outcome of learning skill pasing on volleyball.

Cycle Results 1

Table 4. Distribution of Pasing Data Over Cycle 1

\begin{tabular}{|c|c|c|c|}
\hline Value & $\begin{array}{c}\text { The number } \\
\text { of students }\end{array}$ & Category & Percentage \\
\hline $86-100$ & 0 & $\begin{array}{c}\text { Very } \\
\text { good }\end{array}$ & $0 \%$ \\
\hline $\begin{array}{c}71.00- \\
85.99\end{array}$ & 10 & Good & $25 \%$ \\
\hline $\begin{array}{c}56.00- \\
70.99\end{array}$ & 25 & Enough & $62.5 \%$ \\
\hline $\begin{array}{c}41.00- \\
55.99\end{array}$ & 5 & Less & $12.5 \%$ \\
\hline$<40,99$ & 0 & Very less & $0 \%$ \\
\hline
\end{tabular}

Based on posttest result of cycle 1, it can be explained that student of teacher training and education science faculty UNSRI has increased. It can be seen on posttest result of student is in good category as many as 10 students (25\%), enough category 25 students $(62,5 \%)$, there are fewer category there are 5 student $(12,5 \%)$, and very less category there are 0 students $(0 \%)$.

Results Cycle 2

Table 5. Distribution of Pasing

Data Over Cycle 2

\begin{tabular}{|c|c|c|c|}
\hline Value & $\begin{array}{c}\text { The } \\
\text { number of } \\
\text { students }\end{array}$ & Category & Percentage \\
\hline $86-100$ & 7 & $\begin{array}{c}\text { Very } \\
\text { good }\end{array}$ & $17.5 \%$ \\
\hline $\begin{array}{c}71.00- \\
85.99\end{array}$ & 30 & Good & $75 \%$ \\
\hline $\begin{array}{c}56.00- \\
70.99\end{array}$ & 3 & Enough & $7.5 \%$ \\
\hline $\begin{array}{c}41.00- \\
55.99\end{array}$ & 0 & Less & $0 \%$ \\
\hline$<40,99$ & 0 & Very less & $0 \%$ \\
\hline
\end{tabular}

Based on posttest result of cycle 2, it can be explained that student have significant improvement.
It can be seen on posttest result of student is in very good category as many as 7 students $(17,5 \%)$, in good category 30 students $(75 \%)$, there are enough 3 students $(75 \%)$, and very less 0 students $(0 \%)$.

\section{DISCUSSION}

This research in step to test the effectiveness of a multimedia learning in the form of flash. Multimedia is expected to improve the effectiveness of volleyball learning physical education and health on teacher training and education science faculty UNSRI. This research is held in a basic learning class of volleyball games. This research begins by doing a preliminary test to see how far the student learning skill learning outcomes. The calculated technique is specialized only in upper passing techniques. Instrument used is brady wall volley ball test. Preliminary data obtained before the action was given were 2 students $(5 \%)$ in good category, 12 students $(30 \%)$ in enough category, 23 students $(57,5 \%)$ in less category, and 3 students $(7.5 \%)$ in very less category. See the learning results of the upper pasing skills gained it can be concluded student on semester 2 is in less category. These results shows the need for action that can improve the learning outcomes of volleyball skills. The action given is to use the planned macroflash-based multimedia in classroom action research for 2 cycles.

Cycle 1. Use multimedia interactive (flash) at the beginning of learning

In the first cycle given the action in the form of displaying multimedia (flash) before the practice in the field is done. In the first cycle the multimedia display is limited to the correct top - pass technique . This flash multimedia displays the movement of prefix, core movement and advanced movement. Techniques are displayed using the actual human video is not an animation because if menggunkan animation techniques that have memilki shortcomings. Multimedia after airing then students practice in the field by applying the techniques that have been shown before. To know the improvement of skill pasing above then before the volleyball study ended on posttest in cycle 1 . Posttest result in cycle 1 there are 10 students $(25 \%)$ in good category, 25 students $(62,5 \%)$ in enough category, 5 students $(12.5 \%)$ in the category of less, and in very less category there are 0 students $(0 \%)$. Posttest result in cycle 1 got improvement. This can be seen increasing the number of students who are in good category from 2 students $(5 \%)$ to 10 students $(25 \%)$ in this good category there is an increase of $20 \%$. In the initial test in the category enough there are 12 students $(30 \%)$ after the action increased to 25 students (62.5). In the category less on initial tests in there are 3 students $(7.5 \%)$ and sete 1 ah given action becomes 0 students $(0 \%)$ seen here sil ha increase volleyball skills. The above results indicate an increase in students after being given an action. 
Visible number of students who are in good and sufficient category and no students who are in the category less. Results in cycle 1 can be concluded that there is an increase but for the overall assessment $\mathrm{n}$ students are still sufficient, in accordance with the results of the study [12] are advised to teachers to apply multimedia-based learning to increase students' interest to learn which implies improving student achievement. This study continues in cycle 2 because the increase in learning outcomes is not very significant.

\section{Cycle 2}

This study continued on cycle 2 because in cycle 1 the result of learning skill pasing on student in general is in enough category with result of this research continued to cycle 2 . The action given at siklus 2 is multimedia display (macro flash) which on cycle 1 just aired the upper mounting technique then in cycle 2 is reproduced the upper mounting technique and coupled with the learning models that can improve the learning outcomes of the volleyball skill. This research continues on field practice with top fitting techniques and applying the instructional models that have been presented. To know the improvement then before the end of student learning penjaskes in post $t$ test with instrumens brady wall volley ball test. The result of posttest of students in get 7 students $(17,5 \%)$ in very good category, 30 students $(75 \%)$ in good category, and 3 students $(7.5 \%)$ in enough category. The percentage of overall data was found that the result of learning skill pasing on teacher training and education science faculty UNSRI students was in very good and good category. This shows that the action of multimedia broadcasting (flash) done successfully improve the learning outcomes of volleyball student. This is in accordance with research [13] that the development of interactive multimedia can improve students' motivation and learning outcomes. This classroom action research ends in cycle 2 because it is seen from the average upper learning skill learning outcome of $92.5 \%$ in either category. The results of this study are also supported by the results of research[14]that the application of interactive multimedia assisted instructional learning method can improve students' skills class XI Science of Senior High School Walisongo Semarang.

\section{CONCLUSION}

Based on research results obtained learning game volleyball using multimedia -based macroflash effectively reviewed from the learning results great student of teacher training and education science faculty UNSRI. The effectiveness of multimedia macroflash can be seen through the improvement of learning skill learning outcomes on the game of volleyball with the increasing number of students who scored above 71 . This study resulted in the improvement of learning outcomes seen from preliminary data before the action was done by $25 \%$ in good category after given action in the form of giving multimedia based on macroflash learning result of passing over volleyball increased to $95 \%$ student. Based on this research found findings in the form of an increase in learning outcomes on volleyball because it is given multimedia macroflash. The implications of this research are macroflashbased multimedia can be used as one of the media that can improve the learning result of volleyball game.

\section{ACKNOWLEDGMENT}

This research was supported by Universitas Sriwijaya. We thank our students of physical education and health on teacher training and education science faculty UNSRI class of force 2016.

\section{REFERENCES}

[1] Rosdiani, Dini. Model Pembelajaran Langsung dalam Pendidikan Jasmani dan Kesehatan. Bandung: Alfa Beta.2012, pp.23.

[2] Munasifah. . Bermain Bola Voli. Semarang: CV Aneka Ilmu.2008, pp. 3.

[3] Roblyer, M \& Doering, AH .. Integrating Educational Technology Into Teaching. Boston: Pearson.2010, pp. 170.

[4] Rayanda Asyhar. Kreatif Mengembangkan Media Pembelajaran. Jakarta: GaungPersada (GP) Press Jakarta.2012, pp. 187.

[5] Darmawan, D. Teknologi Pembelajaran. Bandung: PT Remaja Rosdakarya. 2011,pp.151.

[6] Jumadil., Siang Tandi Gonggo \& Sitti Rahmawati. . Peningkatan Hasil Belajar Kimia menggunakan Multimedia pada Materi Ikatan Kimia Kelas X Sekolah Menengah Kejuruan Negeri Parigi Selatan. J. Akad. Kim. 2 (1). pp: 39-46, 2013.

[7] Hadade,. Imron. . Efektivitas Penggunaan Komputer sebagai Media Presentasi terhadap Peningkatan Motivasi dan Hasil Belajar dalam Pembelajaran Penjas. Jurnal Ilmu Pendidikan. pp: 180-194, 2015.

[8] Dean, J. . Improving Children's Learning: Effective Teaching in The Primary School. London: Routledge.2000, pp.51.

[9] Suharsimi Arikunto. ProsedurPenelitian,Suatu Praktek. Jakarta: Bina Aksara.2003, pp.3.

[10] Richard .H . Cox. . Sport Psychology. New York: The Mcgraw-Hill Companies,Inc.2002, pp.101.

[11] Handbook Teacher Training And Education Science Faculty Universitas Sriwijaya. Palembang: Unsri Press.2017, pp. 18

[12] Lisner Tiurma And Heri Retnawati. Keefektifan Pembelajaran Multimedia Materi Dimensi Tiga Ditinjau Dari Prestasi Dan Minat Belajar Matematika Di Sma.Jurnal Pendidikan, Volume 44, Number 2. pp 17518,2014 .

[13] Triyanti, Merti. Development of Interactive Multimedia on Nerve System Material to Improve Motivation and Learning Outcomes of High School Grade XI Students. Journal Bioedukatika Vol. 3 No. 2. ISSN: 2338-6630.pp 9-14,2015.

[14] Syaerozi,et al. Penerapan Metode Pembelajaran Drill Berbantu Multimedia Interaktif untuk Meningkatkan Keterampilan Mengolah Data Menggunakan Microsoft Excel. Jurnal Teknik Elektro Universitas Negeri Semarang. Vol 2. No.2. ISSN 2552 -6811.pp, 2015. 